\title{
A Newly Discovered Hebrew and Greek Inscription, Relating to the Boundary of Gezer
}

\section{Clermont Charles-Ganneau}

To cite this article: Clermont Charles-Ganneau (1899) A Newly Discovered Hebrew and Greek Inscription, Relating to the Boundary of Gezer, Palestine Exploration Quarterly, 31:2, 118-127, DOI: $10.1179 /$ peq.1899.31.2.118

To link to this article: http://dx.doi.org/10.1179/peq.1899.31.2.118

册 Published online: 20 Nov 2013.

Submit your article to this journal \lceil

Џll Article views: 4 
13. At the Haram es Sherif much restoration and oil-painting were done, also many architectural decorations; for instance, the arches over the pillars on the stairs of the platform were plastered over, so that the stones can no more be seen, and then painted fantastically, and so also the frout of the Aksa Mosque, which now looks yellow as if gilded and has a very strarge appearance. Other things were done with better taste.

\section{A NEWLY DISCOVERED HEBREW AND GREEK INSCRIPTION, RELATING TO THE BOUNDARY OF GEZER. ${ }^{1}$}

\section{By Prof. Charles Chermont-Ganneau, LL.D.,} Membre de l'Institut, Professeur au Collège de France.

IT is well known that the town of Gezer has played an important part in the history of Palestine. It was already in existence before the Israelites entered the land of Canaan; in fact, the Book of Joshua mentions the Canaauitish King of Gezer as one of those with whom the new conqueror's had a quarrel to pick, and the testimony of the Bible on this point has been clearly confirmed by the cuneiform tablets discovered at Tell el-Amarna, as well as by the Egyptian records : amongst others, the stela of Merenptah, the date of which is fixed at about the year 1230 B.c. A sacerdotal town under Israelitish dominion, the point of intersection of the boundaries of the territories of Ephraim, Dan, and $\mathrm{Judah}$, a frontier town in the extreme east of the territory of the Philistines, captured and burnt by one of the Pharaohs of Egypt - Gezer had been given by this Pharaoh to his daughter as a dowry when she entered the harem of Solomon, and the ancient city, originally Canaanitish, subsequently Philistine, and finally Jewish, was rebuilt by the Israelitish monarch. During the period of the Maccabees Gezer figures continually in the course of the long struggles carried on by the Jews against the Seleucidæ, and becomes one of the chief bulwarks of the Asmonæan princes. Lastly, considerably later, Gezer-which, as I have already shown;"

1 Read at the Académie des Inscriptions et Belles-lettres, at the meeting of October 28th, 1898.

2 "Recueil d'Archéologie Orientale," vol. i, pp. 352-391: Mront Gisart et Tell.el-Jezer. 
is nothing but the Mount Gisart of the Crusaders, which was so long a topographical enigma-was the scene of a brilliant victory gained by them over Saladin-a victory which at that time was celebrated throughout Christendom, but for which, some few jears later, Saladin exacted a terrible revenge in the disaster of Hattin, which destroyed the Latin Kingdom of the Holy Land.

In spite of the ample historical information and topographical indications furnished by ancient authorities, in spite of all the researches of explorers, the problem of the identification and site of this very important town-a problem which contains the key to many others-had remained insoluble up to the year 1871. Gezer could not be discovered.

At this time, thanks to an apparently unimportant passage, buried in an ancient Arabic chronicle, I was led to suggest the identity of the town of Gezer with an ancient tell or hill, covered with ruins, and occupying a most remarkable strategical position, which still bears, in addition to the common and misleading name of Abu Shûsheh, its primitive Canaanitish name, faithfully preserved under the Arabic form of Tell el-Jezer.

In 1872 I read before our Society, to which I had not at that time the honour to belong, a paper, the object of which was to show that this tell, which did not appear upon any map, and which I had succeeded in discovering on the site, answered to all the historical, topographical, and toponymical data of the problem.

When I had finished reading this paper, our regretted fellow'member, M. Miller, who presided at the meeting, while addressing to the author of the communication the few kind words that are customary on such occasions, thought it his duty to express certain reservations in regard to the value of the arguments which served as the basis of a proof which appeared to him to be somewhat venturesome.

I can eren now call to mind the little touch of irony, although courteously worded, with which the learned Hellenist, making himself the interpreter of the scepticism exhibited in the observations of certain of his fellow members, added that it was to be regretted that I could not produce in support of a thesis, which was rather a hypothesis, the aid of some sound epigraphical argument-for instance, an inscription in situ containing the name of the town in dispute. This was, perhaps, a great deal to 
demand from poor Palestine, which has always shown itself so chary of proofs of this kind. I was therefore obliged to confess, with all humility, that I had only been able to work upon the precarious elements that constitute the foundation of the purely inductive method, to which, alas! all those who study the topography of the Bible are condemned. At that moment I had no idea that, two years later, I should have the unexpected good luck to be enabled to give a complete answer to this request; which perhaps brought me good fortane, and to discover, on the very site which I had assigned to Gezer, not one inscription, but a series of decisive inscriptions, which at once justifies, specifically, my theoretical views and, what is perhaps even more important, the general method which had guided them and the value of which had been so seriously called in question.

In fact, in 1874, having had the opportunity of revisiting the spot in the course of the mission with which I had been entrusted by the Palestine Exploration Fund, I discovered, carved upon the rock about 800 metres to the direct east of Tell el-Jezer, a bilingual inscription, in large Greek and Hebrew characters, containing these simple words, singularly significant in their brevity: 'Aגкiov, תתם ג' "boundary of Gezer, of Alkios." This Greek, or rather Jewish-Greek, name Alkios in the genitive case, is probably that of the civil or religious magistrate who had presided at the settlement of this official boundary about the time of the Maccabees-to judge from the palæography of the characters. The identity of Gezer and Tell el-Jezer was accordingly established, this time in such a manner as to satisfy the must exasting criticism.

Struck by the fact that this epigraphical landmark was normally oriented in reference to the tell, I concluded that the boundary in question must be a boundary surrounding the city, and not simply a line of demarcation, passing, for instance, between two contiguous territories; in the latter case, in fact, we shouid expect to find the second territory mentioned: "Boundary of Gezer and ...." Remembering that Gezer had been a Levitical city, I was led to suppose that we might have to do with the delimitation of the sacred zone, the migrash that surrounded the Levitical cities, a zone which in many respects recalls the $\pi \rho$ oa $\sigma \tau \epsilon \iota \nu$ or pomerium of classical antiquity, and which seems later to have served to fix the legal distance of 
the well-known "Sabbath day's journey" ( שבת), mentioned in the Acts of the Apostles and the Talmud. Starting from this idea, I drew the inference that this epigraphical landmark could not be isolated, and that a whole series of others should certainly be discovered round the site of Gezer, at perceptibly equal distances and at points distributed according to normally oriented lines. The Bible, in fact, tells us that the sides of the migrash were oriented according to the cardinal points.

This reasoning was soon justified by the result. Prosecuting my search along a line drawn by the compass from S.E. to N.W., I soon discovered, at a distance of about 150 metres from the first inscription, a second, carved like the first upon the rock, and absolutely identical in purport: "Boundary of Gezer, of Alkios." The only difference is that in this case the two texts were arranged back to back, instead of being put end to end as in the first case. Further, between these two inscriptions I discovered a third, purely Hebrew, shorter, and difficult of interpretation.

I immediately had these precious docaments excised in order to protect them from the chances of destruction which they had hitherto miraculously escaped. Unfortunately a conflict with the local authorities, stirred up by the treachery of certain Europeans settled in the Holy Land whom I had been foolish to trust, abruptly cut short my researches in the neighbourhood of Gezer. It was not until seven years later, when I revisited Palestine in 1881, that I was able to resume them, and then only incompletely. On again passing the site of Gezer I discovered, still in the same direction, S.E. to N.W., a third copy of the bilingual inscription of the boundary of Gezer. This time, the two texts, still identical and carved in large letters upon the rock, were superposed.

Meanwhile, having been suddenly called back to France, I was unable to carry out my plan of thoroughly exploring the environs of Gezer in order to find the other similar epigraphical landmarks, which, in my opinion, were bound to exist upon the other sides (north, west, and south) of the migrash. When publishing, in the second volume of my "Archæological Researches in Palestine," 1 my complete examination of the question of Gezer, I earnestly brought this desideratum to the notice of future explorers.

My appeal has been heard. Père Lagrange, whose learning and activity our Society has frequently had occasion to appreciate,

${ }^{1}$ Lon $70 n$, 1896, pp. 224-265. 
informs me that, with the assistance of the Fellâhîn of the district, whom I had formerly directed to follow this track, he had just discovered a fourth copy of the boundary inscription, carved upon the rock, and to the same effect. Here is the rough copy which he has been good enough to send me, which was taken by Père Delau :-

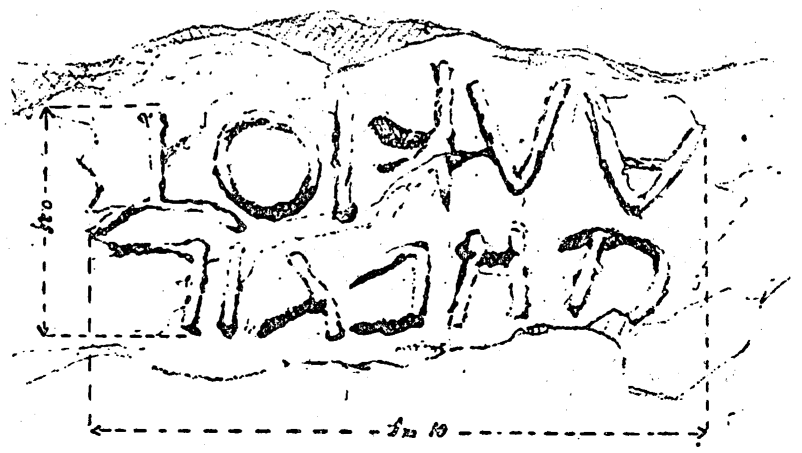

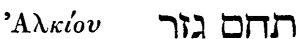

(Hebrew) Limit of Gezer. (Greek) of Alkios.

It will be observed that the arrangement of the two texts is identical with that of my copy, C, that is to say, that the Hebrew and Greek lines are back to back. The inscription as a whole is $1 \cdot 10$ metres long by $0 \cdot 25$ (?) metre high. ${ }^{1}$

The discovery of this fresh text, confirmatory of the preceding ones, is in itself very interesting. But what is of special importance is the position which the text occupies in reference to Tell elJezer and other congeneric texts. It is, in fact, situated due south of the tell, and consequently in quite a different quarter from the first group of inscriptions situated on the east; this tends to prove, as I had previously supposed, that the intended boundary is really a line limiting a zone that surrounded the town.

The question, which I bave examined at length elsewhere, is: What was the form of this zone, was this limited area a circle or a square? The south-east north-west direction of the four first inscriptions discovered by me (A, C, D, and, by way of

1. On the other hand, Père Delau says in a note that the average height of the letters is 0.20 metre, which it is not easy to reconcile with 0.25 metre as the total height of the two lines. Besides, in another more compendious sketch, two superposed figures are given, $0.25+0.17$, or a total height of 0.42 metre, which is more probable. 
support, B), compared with the description of the migrash of the Levitical cities as given in the Bible, had led me to think that this area might be a square, comparable in certain respects with the square area of the ager publicus of the Roman cities and colcnies, with its two chief lines of direction, the cardo maximus (north to south) and the decumanus maximus (east to west), intersecting at a right angle, and with its extremitates marked by the termini territoriales.

On the other hand, the distribution of these inscriptions along an oblique line proceeding from east to north seemed to indicate that this square was set. towards the four cardinal points, not by its sides, as might a priori appear natural (and as is the case with the Roman ager publicus), but by its angles. Père Vincent, taking into consideration these various items of information with which I had furnished him, drew up the little topographical diagram below, which is intended to show the relative position of the recently discovered text.

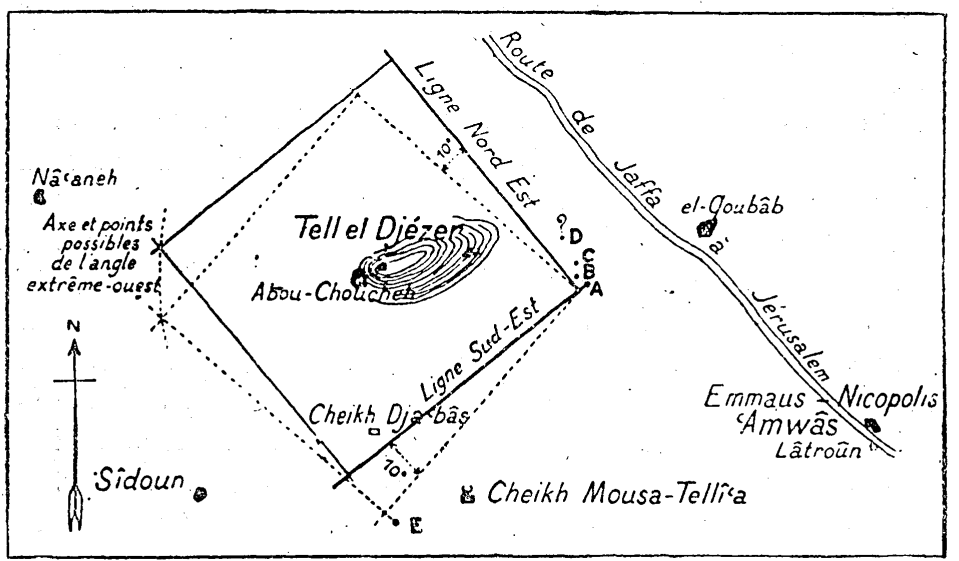

A.C. Bilingual inscriptions of the boundary of Gezer, discovered in 1874, by M. Clermont-Ganneau.

D. Bilingual inscription of the boundary of Gezer, discovered in 1881, by M. Clermont-Ganneau.

B. Hebrew inscription of the boundary of Gezer, discovered in 1874, by M. Clermont-Ganneau.

E. New bilingual inscription, discovered in 1898 .

This position is still only approximate. It would be of great importance to fix the point with great exactness; by mensuration and triangulation. The square in thick lines, which is based 
upon the inscription. A, considered as the extreme eastern landmark, represents the theoreticai square, accurately arranged in accordance with the plans of the Ordnance Survey.

The square in dotted lines represents that constructed on the right, joining the two inscriptions, A E, and hypothetically regarded as its south-east side; it apparently exhibits a deviation of about 10 degrees, with true orientations-a deviation which would be by no means excessive, especially if, as is possible, the ancient orientation was fixed by one of the solstitial points, not by the equinoctial point.

Until we are better informed, the new fact introduced into this particular problem, which is of special interest for Biblical exegesis, is not unfavourable to the theory of a square area, set by its angles. But the problem can only be finally solved by a complete and rigorously accurate survey of the ground, showing the malhematical position of the points indicated by the inscriptions. It is the more earnestly to be desired that this work should be undertaken, as it would doubtless bring about fresh epigraphical discoveries of the same kind. I will therefore permit myself to express the wish that the Académie will entrust. the task to Père Lagrange, who is so admirably fitted to undertake it, and at the same time place at his disposal the means necessary to accomplish it.

I will add, but without insisting for the present upon a scheme which I do not conceal from myself presents difficulties of every kind, that the tell of Gezer itself would certainly seem to be one of the most likely spots in Palestine for methodical excarations. Digging could be carried on there with assurance of successful results, thanks to the certainty, unique of its kind, that we possess relative to the identity of the site. Everything there would be of interest, from the layer of the Crusades that covers tine surface, to the deep layers in which are hidden the remains of a past anterior to the Exodus. Why should we attack, as is too frequently done, somewhat at haphazard, tells that are anonymous or of doubtful origin, and neglect this particular one (as has hitherto been the case), when it possesses the inestimable advantage of having a name that is known, a personality that is ascertained, and a continuous history of its own, intimately connected with the general history of Palestine from the most distant times to the era of the Crusades? 
While exploring the environs of Gezer, Père Lagrange and his companions observed in the little wely of Sheikh Mûsa (Mûsa Tali $\hat{\imath}^{\prime} a$ ), not far to the south of Gezer, beyond Sheikh Ja'bās, a curious capital in white marble with thick veins., The annexed sketches, which Père Vincent made with great care, and the little note which accompanies them, relieve me from the necessity of further description.
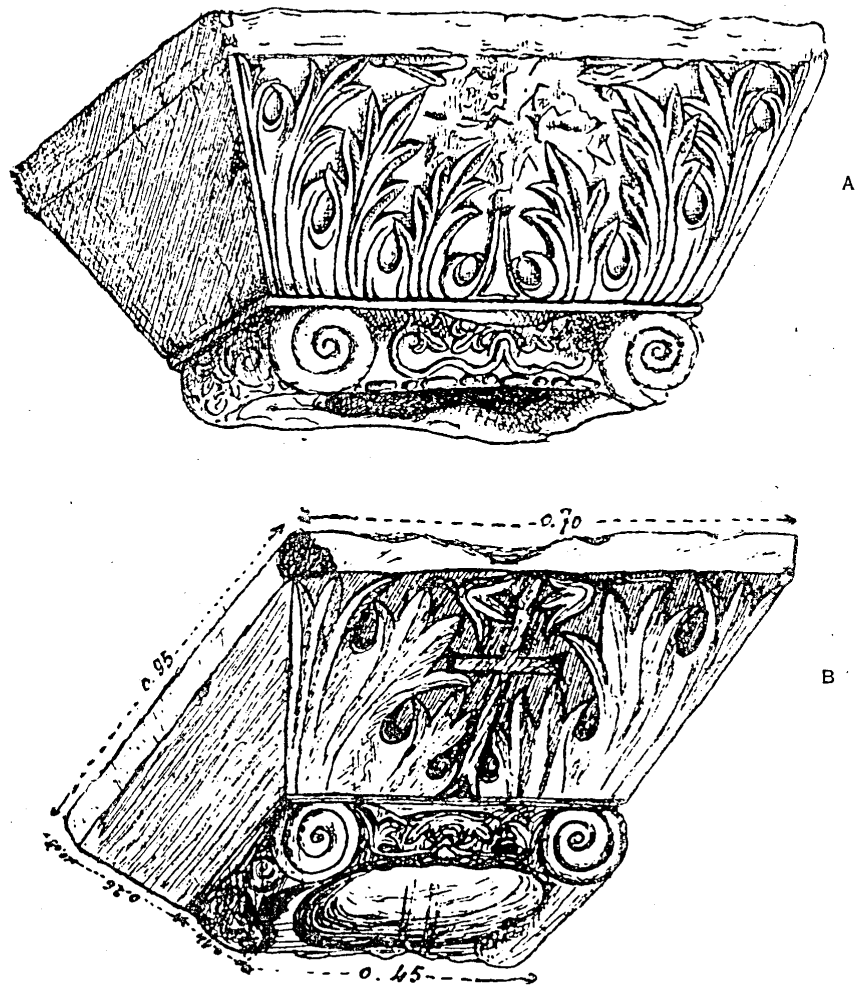

Order very composite. The large faces are bare, with the exception of the volutes. The face, $A$, is of finer workmanship than $B$, in which the arrangement of the acanthuses is irregular. The cross has been partly hammered.

I had already seen this capital in 1874 , and had been struck by its curious form. I had greatly regretted that the circumstances to which I have alluded above, and which had abruptly put an end to my researches in this district, bad prevented me 
from making a drawing of it. Thanks to Père Vincent, this want is now supplied.

On this subject I may be allowed to quote the few lines following, from vol. ii of my "Archæological Researches in Palestine" (p. 236):-

"Further on, and to the south-east, on the top of a hill, rises the sanctuary of Mûsa Talì'a, or esh Sheîkh Mûsấ Talî́a. It consists of a small kubbeh of rough masonry work, with a court in front of it ; the tomb is original. Close by is a large cistern, with its mouth fashioned out of a fine marble capital, carred on two sides. I regret that I did not make a drawing of this. I found no trace of the inscription which $I$ had been told the previous June was to be found there, but it does not follow that it is not really there. The holy person answering to the name of Mûsa was placed there, so the fellâhîn say, as a 'scout' (talî‘ $a$ ), to 'observe' (طل ) the movements of the Christians, who were fighting with the Musulmans in the Wâd es Serâr. The Christians surprised him at his post and killed him; he died the death of the martyrs (Shehîd). It is a fact that the spot is situated on a commanding point, whence there is a very fine and extensive view. The three points, Tell el-Jezer, Sheîkh Ja'bâs, and Sheîkh Mûsa, are similarly situated in this respect; accordingly the fellâhîn

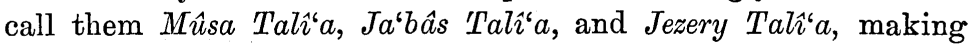
these three more or less real personages into three warriors of old, placed as scouts on the three places that command the region round about. I am greatly inclined to believe that there is a hidden historical basis to the legend of Mûsa Talî‘a, some incident of the great battle of Mount Gisart, between Saladin and the Franks, and that Mount Gisart, the site of which has remained absolutely unknown up to the present time, was, as I shall explain later on, none other than our Tell el-Jezer."

On seeing again, after an interval of more than twenty-four years, the faithful representation of this capital, I ask myself now whether this last impression was not correct. May not the preserce of the cross (of the form called Latin) on the two faces of the capital indicate a work of the Crusaders, although certainly the acanthus leaves and the bastard volutes rather lead us to think of a Byzantine work, and this particular form of the cross is by no means unknown to Byzantine art? To answer this question with any degree of precision, it would be necessary to re-examine 
the monument closely, and ascertain whether, in any of its parts, it happens to present the characteristic diagonal strice of the Crusaders' stone dressing. In this case we should be justified in supposing that the capital may come from some church dedicated to St. Catherine of Mount Gisart, the existence of which I have already deduced from the fact that the great battle won by the Crusaders over Saladin at this spot was fought on St. Catherine's Day. ${ }^{1}$

Be it understood that it is only with considerable reserve that I venture this hypothesis relative to the origin of the capital. I will only observe that in its general form, if not in its ornamentation, it offers a certain analogy with three marble capitals, also quadrangular, discovered 'by me in 1881 in the same neighbourhood, at $\mathrm{Ni}$ 'âneh, a little village not far to the east_of Tell el-Jezer. ${ }^{2}$

\section{THE RUINS OF THE HERODIAN JERICHO.}

By the Rev. J. E. Hanader.

When down at Jericho recently I rode over with the Rev. Dr. Nies to examine the remains at Khirbet es Sumra, on the northern bank of Wad en Nitei'ameh. I am convinced that this was the site of Herod's Jericho. The remains are most extensive, but are being destroyed rapidly by searchers for building stones. We noticed debased Roman capitals, bits of spirally-fluted column shafts, and a great many Roman fire-tiles belonging to baths. Also indications of two or three well-built circular or oval chambers connected with the baths, and perhaps marking either the position of boilers or laconica and sudatories.

I know that Dr. Bliss gave a general plan of these ruins in the Quarterly Statement (1894, p. 175) some years ago, but a more detailed plan, arid an attempt at restoration and comparison with other plans of

1 See, on this question, the chapter in vol. i of my "Recueil d'Archéologie Orientale," quoted above.

2 I deposited the originals in the Lourre and have given reproductions of them in my "Rapports sur une Mission en Palestine et en Phénicie entreprise en 1881," pp. 63, 64, Nos. 17, 18, 19. No. 17 bears, inscribed on a crown, the well-known formula, EIC $\Theta \in O C$ (one God), which is also found again upon the famous bilingual capital of Emmaus, in Greek and Hebrew-Samaritan. The acanthus leaf of No. 18 zomewhat resembles those of the capital of Mûsa Tali'a. 